\title{
ISOLASI DAN UJI POTENSI FUNGI ENDOFIT KULIT BATANG LANGSAT (Lansium domesticum Corr.) PENGHASIL ANTIBAKTERI TERHADAP Staphylococcus aureus DAN Escherichia coli
}

\author{
Andi Indrawati ${ }^{1 *}$, Nur Aeni Hartih ${ }^{2}$, Muyassara ${ }^{3}$ \\ ${ }^{1,2,3}$ Fakultas Farmasi Universitas Indonesia Timur \\ ${ }^{*}$ Koresponden Email: andindrawaty2303@gmail.com \\ zara.champa04@gmail.com
}

DOI: https://doi.org/10.32382/mf.v15i1.776

\begin{abstract}
Endophytic microbes (fungi or bacteria) contained in plants do not cause visible damage, and are capable of producing secondary metabolites according to their host plants. Endophytic fungi in vitro produce active metabolites that can function as antibacterial, herbicidal and natural pesticides. One of the plants that has been studied previously is that endophytic fungi are langsat (Lansium domesticum) (Fety, 2015). Stems of langsat contain flavonoids, saponins, tannins, and triterpenoids which are thought to be antibacterial compounds. The aim of the study was to isolate the endophytic fungi of antibacterial stem bark against Staphylococcus aureus and Escherichia coli. This study used the isolation and agar diffusion method (Kirby Bauer). The results obtained were 2 endophytic fungi isolates; isolate I is Rhizopus sp. and isolate II, namely Aspergillus sp. The antibacterial potential test of isolates I and II isolates against Staphylococcus aureus and Escherichia coli each had an average inhibition zone diameter of $15.67 \mathrm{~mm} ; 11.67 \mathrm{~mm}$ and $17.76 \mathrm{~mm} ; 21.93 \mathrm{~mm}$. Based on the results of the study, the two endophytic fungi isolates on langsat bark have the potential as antibacterial against Staphylococcus aureus and Escherichia coli.
\end{abstract}

Key word : Endophytic Fungi, Lansium domesticum, Staphylococcus aureus, Escherichia coli

\section{ABSTRAK}

Mikroba (fungi atau bakteri) endofit yang terdapat di dalam tanaman tidak menimbulkan kerusakan yang tampak, dan mampu memproduksi metabolit sekunder sesuai dengan tanaman inangnya.Fungi endofit secara in vitro memproduksi metabolit aktif yang dapat berfungsi sebagai antibakteri, herbisida dan juga pestisida alami. Salah satu tanaman yang telah diteliti sebelumnya terdapat fungi endofit di dalamnya adalah tanaman langsat (Lansium domesticum) (Fety, 2015). Batang tanaman langsat mengandung senyawa flavonoid, saponin, tannin, dan triterpenoid yang diduga sebagai senyawa antibakteri. Tujuan penelitian yaitu untuk mengisolasi fungi endofit kulit batang langsat penghasil antibakteri terhadap Staphylococcus aureus dan Escherichia coli. Penelitian ini menggunakan metode isolasi dan difusi agar (Kirby Bauer). Hasil yang diperoleh terdapat 2 isolat fungi endofit; isolat I yaitu Rhizopus sp. dan isolat II yaitu Aspergillus sp. Uji potensi antibakteri isolat I dan isolat II terhadap Staphylococcus aureus dan Escherichia coli masing-masing memiliki diameter zona hambat rata-rata $15,67 \mathrm{~mm} ; 11,67 \mathrm{~mm}$, dan 17,76 mm; $21,93 \mathrm{~mm}$. Berdasarkan hasil penelitian, maka kedua isolat fungi endofit pada kulit batang langsat berpotensi sebagai antibakteri terhadap Staphylococcus aureus dan Escherichia coli.

\section{Kata kunci : Fungi Endofit, Lansium domesticum, Staphylococcus aureus, Escherichia coli}

\section{PENDAHULUAN}

Tingkat produksi obat herbal khususnya saat ini masih sangat terbatas karena sebagian besar bahan baku masih diambil dari tanaman aslinya. Dikhawatirkan sumber daya hayati ini suatu saat musnah disebabkan kendala dalam budidayanya dan peningkatan produksi yang sejalan dengan 
meningkatnya permintaan akibat berkembangnya populasi (Kuncoro, 2011). Salah satu cara yang dapat dilakukan untuk mengatasi kendala tersebut, yaitu dengan memanfaatkan sumber daya hayati yang ada tanpa merusak atau mengganggu stabilitas ekosistemnya, dan memanfaatkan senyawa metabolit yang dihasilkan oleh mikroba (fungi atau bakteri) pada tanaman.

Endofit berasal dari dua kata yakni endon yang berarti di dalam, dan pyton berarti tanaman. Endofit bermakna mikroorganisme, baik itu fungi atau bakteri yang hidup di dalam tanaman tanpa menimbulkan kerusakan yang tampak (Hakim, 2015). Endofit ini mampu memproduksi metabolit sekunder sesuai dengan tanaman inangnya (Radji, 2005).

Berbagai penelitian menunjukkan bahwa fungi endofit bisa memberikan manfaat positif pada tanaman inang. Dalam interaksi tersebut terdapat hubungan mutualisme antara fungi endofit dengan tanaman. Hampir $80 \%$ fungi endofit secara in vitro memproduksi metabolit aktif yang berguna sebagai antibakteri, herbisida dan juga pestisida alami (Hakim, 2015).

Persentasi adanya fungi endofit pada tanaman relatif cukup tinggi yakni sekitar 70-100\%. Fungi endofit bisa dijumpai pada berbagai bagian tanaman antara lain daun, batang, pucuk dan akar (Hakim, 2015).

Tanaman langsat merupakan tanaman yang telah lama digunakan dalam pengobatan tradisional. Kulit batang digunakan sebagai obat diare, disentri, cacing, demam, malaria, penyembuh bekas gigitan serangga dan tumor (Lawalata, 2012). Secara empiris, masyarakat Kabupaten Pidie, Banda Aceh memanfaatkan batang langsat sebagai obat raphuek (bisul di kepala) (Rubiah,dkk., 2015).

Berdasarkan penelitian sebelumnya oleh Korompis, dkk., 2010, tentang aktivitas antibakteri dari tanaman langsat (Lansium domesticum) terhadap beberapa bakteri patogen. Hasil yang diperoleh bahwa ekstrak kulit batang, kulit buah dan biji buah langsat (Lansium domesticum) memiliki aktifitas antibakteri terhadap Staphylococcus aureus, Escherichia coli, Salmonella typhi dan Vibrio cholera.
Penelitian sebelumnya mengenai analisis fitokimia pada kulit batang basah dan kering langsat oleh Semuel, 2008., mendapatkan hasil bahwa kulit batang langsat memilki kandungan kimia berupa alkaloid, flavonoid, saponin, tanin dan triterpenoid. Kandungan kimia hasil metabolit sekunder inilah yang diduga sebagai senyawa antibakteri.

Tujuan penelitian ini yaitu mengetahui jenis fungi endofit pada kulit batang langsat (Lansium domesticum), dan potensi fungi endofit sebagai penghasil senyawa antibakteri terhadap Staphylococcus aureus dan Escherichia coli.

\section{METODE}

\section{Waktu dan Tempat Penelitian}

Penelitian ini dilakukan pada bulan Juli sampai Agustus 2018 di Laboratorium Mikrobiologi Farmasi, Fakultas Farmasi Universitas Indonesia Timur Makassar.

\section{Alat dan Bahan}

Alat yang digunakan adalah autoklaf, bunsen, cawan petri, corong kaca, erlenmeyer, gelas ukur $100 \mathrm{~mL}$, gelas objek, gelas penutup, inkubator, jarum preparat, jarum ose, jangka sorong, LAF (Luminar Air Flow), labu ukur $10 \mathrm{ml}$, mikroskop, oven, pinset, pipet volume, rak tabung, silet, tabung reaksi dan timbangan analitik.Bahan yang digunakan aquadest steril, aluminium foil, biakan Esherichia coli, biakan Staphylococcus aureus, etanol 70\%, kulit batang langsat, Media Nutrient Agar (NA), Media Potato Dextrose Agar (PDA), Kapas, Kloramfenikol, swab steril, paper disk, dan tissue.

\section{Prosedur Kerja}

Pengambilan dan pengolahan sampel

Sampel yang diambil berupa kulit batang Langsat yang diperoleh dari Kecamatan Campalagian, Kabupaten Polewali Mandar, Provinsi Sulawesi Barat. Setelah itu dicuci bersih dengan air mengalir.

\section{Sterilisasi alat}

Beberapa alat yang digunakan melalui tahap sterilisasi. Sterilisasi ini bertujuan untuk mematikan semua bentuk kehidupan mikroorganisme yang ada pada 
alat, khususnya alat-alat dari gelas disterilkan dalam oven pada suhu $180^{\circ} \mathrm{c}$ selama 2 jam. Sedangkan alat ose dan pingset disterilkan dengan cara pemijaran diatas api spiritus. Alat yang mempunyai ukuran atau berskala disterilkan pada autoklaf dengan suhu $121^{\circ} \mathrm{C}$ selama 15 menit.

\section{Pembuatan medium PDA dan NA} Potato Dexstrosa Agar (PDA) ditimbang sebanyak 3,9 gram dan kloramfenikol $10 \mathrm{mg}$ kemudian dimasukkan dalam Erlenmeyer, dilarutkan dengan Aquades hingga $100 \mathrm{ml}$ dicek $\mathrm{pH}$ nya sampai 7,0 $\pm 0,2$. Setelah itu dipanaskan sampai mendidih dan larut sempurna.Setelah larut sempurna disumbat kapas lalu disterilkan dalam autoklaf selama 15 menit pada suhu $121^{\circ} \mathrm{C}$. Nutrient Agar (NA) ditimbang sebanyak 2 gram, kemudian dimasukkan ke dalam Erlenmeyer, dilarutkan dengan Aquades hingga $100 \mathrm{ml}$ dicek $\mathrm{pH}$ nya sampai 7,0 $\pm 0,2$. Setelah itu dipanaskan sampai mendidih dan larut sempurna. Setelah larut sempurna disumbat kapas lalu disterilkan pada autoklaf selama 15 menit pada suhu $121^{\circ} \mathrm{C}$.

\section{Penyiapan bakteri uji}

Satu ose biakan murni Escherichia coli dan Staphylococcus aureus diinokulasikan pada media Agar miring, lalu diinkubasi pada suhu $37^{\circ} \mathrm{C}$ selama 24 jam. Hasil peremajaan yang diperoleh, diambil 1 ose lalu disuspensikan dalam $10 \mathrm{ml} \mathrm{NaCl}$ fisiologis $0,9 \%$.

\section{Isolasi fungi endofit}

Kulit batang langsat dicuci dengan air mengalir, lalu dipotong kecil $3-4 \mathrm{~cm}$. Setelah itu disterilisasi dengan cara direndam dalam etanol $70 \%$ selama 2 menit. Bilas dengan aquadest steril sebanyak 3 kali.Potongan kulit batang ditanam pada media PDA yang telah ditambahkan kloramfenikol, lalu di inkubasi pada suhu kamar $\left(25^{\circ} \mathrm{C}-28^{\circ} \mathrm{C}\right)$ selama 3 hari atau sampai terdapat pertumbuhan fungi.

\section{Pemurnian isolat fungi endofit}

Fungi endofit yang tumbuh pada medium PDA, dimurnikan pada medium PDA dan diinkubasi selama 3 hari pada suhu $25^{\circ} \mathrm{C}$. Setelah itu, jamur yang tumbuh diamati bentuk dan warna koloninya. Setiap koloni yang berbeda bentuk maupun warnanya disubkultur lagi pada medium PDA miring sampai diperoleh koloni murni.

\section{Karakteristik Fungi Endofit}

Media PDA diambil dari cawan petri dengan jarum ose, kemudian potongan media tersebut diletakkan di atas gelas objek. Jamur dari biakan murni diambil dengan jarum ose lalu inokolum jamur diletakkan di atas potongan media pada objek glass lalu ditutup dengan gelas penutup. Preparat tersebut diletakkan di atas tissue basah yang diletakkan di atas nampang plastik, lalu diinkubasi selama 3 hari. Setelah itu dilakukan pengamatan secara makroskopik dan mikroskopik.

\section{Uji AntagonisFungi Endofit}

Uji antagonis dilakukan untuk mengetahui potensi dari fungi endofit untuk menghasilkan antibakteri. Medium NA dituang secara aseptis ke dalam cawan petri steril sebanyak $15 \mathrm{ml}$ dan dibiarkan memadat. Setelah itu diambil suspensi Escherichia coli dan Staphylococcus aureus diinokulasikan pada masing-masing permukaan media NA dengan menggunakan swab steril. Isolat fungi endofit disuspensikan dengan aquadest steril, lalu paper disk direndam dalam suspensi jamur endofit sekitar 15 menit. Setelah itu ditiriskan dan diletakkan di atas medium NA yang telah diinokulasi dengan bakteri uji. Diinkubasi pada suhu $37^{\circ} \mathrm{C}$ selama 24 jam. Setelah itu dilakukan pengukuran diameter zona hambat.

\section{HASIL}

Hasil pengamatan secara makroskopik dan mikroskopik isolat fungi endofit dari kulit batang langsat didapatkan 2 jenis isolat murni dengan karakteristik yang berbeda, seperti pada tabel 1 dan 2, sedangkan hasil pengukuran diameter zona hambat pada pengujian fungi endofit sebagai penghasil antibakteri terhadap Staphylococcus aureus dan Escherichia coli seperti pada tabel 3 dan 4 .

\section{PEMBAHASAN}

Hasil isolasi didapatkan dua jenis isolat fungi endofit. Isolat I tumbuh pada hari ke-3, dengan karakteristik berwarna 
putih kemudian coklat tua karena warna coklat dari sporangiofor, permukaan bertekstur kasar. Pada pengamatan mikroskopik jamur endofit memiliki hifa asepta yang merupakan ciri dari fungi kelas Zygomycetes, sporangia bulat, kolumela bulat, sporangiofor coklat. Pada isolat II, tumbuh setelah hari ke-4, berwarna putih kemudian hijau kebiruan karena lebatnya konidiofor, permukaan bertekstur benangbenang halus, sedangkan pada pengamatan mikroskopik memiliki hifa bersepta yang merupakan salah satu ciri fungi kelas Ascomycetes, vesikel bentuk gada, konidia elips, dan konidiofornya berwarna hialin. Berdasarkan hasil tersebut, isolat I memiliki karakteristik seperti Rhizopus sp. dan isolat II memiliki karakteristik seperti Aspergillus sp. (Gandjar, dkk., 2000).

Kedua jenis isolat fungi endofit tersebut selanjutnya diujikan terhadap Staphylococcus aureus dan Eschericia coli untuk melihat potensi antibakterinya. Hasil positif ditandai dengan terbentuknya zona bening disekitar isolate fungi endofit. Hal ini menandakan terjadinya penghambatan pertumbuhan terhadap Staphylococcus aureus dan Eschericia coli.

Berdasarkan hasil uji antagonis fungi endofit kulit batang langsat terhadap Staphylococus aureus dan Escherichia coli setelah inkubasi selama 24 jam mendapatkan hasil positif, dimana zona hambat yang terbentuk dari isolat I terhadap Staphylococcus aureus dan Escherichia coli masing-masing memiliki diameter zona hambat rata-rata $15,67 \mathrm{~mm}$ dan $17,76 \mathrm{~mm}$, sedangkan pada isolat II yang diujikan terhadap Staphylococcus aureus dan Escherichia coli masing-masing memiliki diameter zona hambat rata-rata $11,67 \mathrm{~mm}$ dan 21,93 mm.

Hal tersebut membuktikan bahwa metabolit sekunder dari jamur endofit yang berasal dari kulit batang langsat dapat berpotensi sebagai antibakteri. Pernyataan tersebut didukung oleh pendapat Carrol dalam Worang (2003), yang menyatakan bahwa jamur endofit dapat menghasilkan mikotoksin, enzim dan antibiotika. Seperti pada hasil penelitian oleh Wahyuni et al, 2016, menemukan adanya jamur endofit Aspergillus sp. dari tanaman tebu (Saccharum officinarumL.) yang dapat menghambat pertumbuhan Xanthomonas albilineans L. penyebab penyakit vaskular bakteri, dengan diameter zona hambat sebesar 4,40 mm.

Secara umum kandungan kulit batang langsat basah dan kering memiliki beberapa kandungan kimia seperti alkaloid, flavonoid, saponin, tanin dan triterpenoid (Semuel, 2008). Berdasarkan hal tersebut, dapat dibuktikan bahwa jamur endofit memilikiperan penting dalam pertumbuhan bakteri, karena di dalam jamur endofit terdapat metabolit sekunder yang didapatkan dari inangnya. Kemungkinan besar adanya zat aktif yang sama dengan tanaman tersebut karena rekombinasi genetik yang terjadi antara jamur endofit dengan tumbuhan inangnya dalam waktu yang cukup lama (Azevedo et al, 2000).

Hasil penelitian ini juga menunjukkan bahwa fungi endofit jenis Rhizopus sp. dan Aspergillus sp. yang diisolasi dari kulit batang langsat berpotensi sebagai antibakteri yang dapat menghambat pertumbuhan Staphylococcus aureus dan Escherichia coli.

\section{KESIMPULAN}

Berdasarkan hasil penelitian yang telah dilakukan maka dapat disimpulkan bahwa :

1. Hasil isolasi fungi endofit dari kulit batang langsat diperoleh dua jenis isolate, yaitu isolat I yang memiliki karakteristik yang sama dengan Rhizopus sp. dan isolat II yang memiliki karakteristik yang sama dengan Aspergillus sp.

2. Kedua jenis isolat fungi endofit tersebut berpotensi sebagai antibakteri terhadap Staphylococcus aureus dan Escherichia coli

\section{UCAPAN TERIMAKASIH}

Ucapan terimakasih disampaikan kepada pihak Laboratorium Mikrobiologi dan Fakultas Farmasi Universitas Indonesia Timur yang telah banyak membantu dan memfasilitasi terlaksananya penelitian ini hingga selesai.

\section{DAFTAR PUSTAKA}

Azevedo, et al. 2000. Plant Biotechnology

Enviromental Biotechnology, Endophytic Microorganisms. 
Jurnal Elektronik Bioteknologi, Vol. 3, No. 1.

Feti, Siti khotimah dan Mukarlina.2015. Uji Antagonis Jamur Rizosfer Isolat Lokal terhadap Phytophthora sp. yang Diisolasi dari Batang Langsat (Lansium domesticum Corr). Protobiont (2015) Vol. 4 (1) : 218-225

Gandjar, dkk.2000. Pengenalan Kapang Tropic Umum. Yayasan Obor Indonesia : Jakarta

Hakim, S.S. 2015.Fungi Endofit: Potensi dan Pemanfaatannya Dalam Budidaya Tanaman Kehutanan, Vol 1 Nomor 1.

Kuncoro, Hadi. 2011. Jamur Endofit, Biodiversitas, Potensi Dan Prospek Penggunaannya Sebagai Sumber Bahan Obat Baru. Vol 1. No. 3

Lawalata, V.N. 2012.Rekayasa Proses Ekstraksi Kulit Buah Langsat (Lansium domesticum) Sebagai Bahan Antibakteri Dan Antioksidan. Bogor. Tesis Program Pascasarjana - IPB..
Radji, Maksum. 2005. Peranan Bioteknologi Dan Mikroba Endofit Dalam Pengembangan Obat Herbal. Majalah Ilmu Kefarmasian. Vol. II, No. 3.

Rubiah, dkk. 2015. Kajian Etnobotani Obat Penyakit Kulit Pada Masyarakat Kabupaten Pidie. Jurnal Biologi Edukasi Edisi 14, Volume 7 Nomor 1.. 2014.

Semuel, M.Y. 2008. Aktivitas Antioksidasi Dan Antikanker Ekstrak Kulit Batang Langsat (Lansium domesticum L). Bogor. Tesis Program Pascasarjana - IPB.

Worang, RI. 2003. Fungsi Endofit Sebagai Antibiotika. Makalah Pengantar Falsafah Sains Program Pasca Sarjana Institusi Pertanian Bogor: Bogor.

Wahyuni, et al. 2016.Identifikasi dan Antagonisme Jamur Endofit Tanaman Tebu (Saccharum officinarum L.) dalam Menghambat Xanthomonas albilineans L. Penyebab Penyakit Vaskular Bakteri. Jurnal Pertanian Tropik, Vol. 3, No.1, Hal 31-42. 
Tabel 1.Karakteristik isolat I fungi endofit dari kulit batang Langsat (Lansium domesticum)

\begin{tabular}{|c|c|c|c|}
\hline \multirow[b]{2}{*}{ Kode Isolat } & \multicolumn{2}{|c|}{ Katakteristik } & \multirow{2}{*}{ Jenis Fungi } \\
\hline & Makroskopik & Mikroskopik & \\
\hline Isolat I & $\begin{array}{l}\text { - Tumbuh hari ke-3 } \\
\text { - Berwarna putih } \\
\text { kemudian coklat tua } \\
\text { - Permukaan } \\
\text { bertekstur kasar }\end{array}$ & $\begin{array}{l}\text { - Hifa asepta } \\
\text { - Sporangia bulat } \\
\text { - Kolumela bulat } \\
\text { - Sporangiofor } \\
\text { coklat }\end{array}$ & Rhizopussp. \\
\hline
\end{tabular}

Tabel 2. Karakteristik isolat II fungi endofit dari kulit batang Langsat (Lansium domesticum)

\begin{tabular}{|c|c|c|c|}
\hline \multirow[b]{2}{*}{ Kode Isolat } & \multicolumn{2}{|c|}{ Karakteristik } & \multirow{2}{*}{ Jenis Fungi } \\
\hline & Makroskopik & Mikroskopik & \\
\hline Isolat II & $\begin{array}{l}\text { - Tumbuh hari ke-4 } \\
\text { - Berwarna putih } \\
\text { kemudian hijau } \\
\text { kebiruan } \\
\text { - Permukaan } \\
\text { bertekstur benang- } \\
\text { benang halus }\end{array}$ & $\begin{array}{l}\text { - } \text { Hifa bersepta } \\
\text { - Vesikal bentuk } \\
\text { gada } \\
\text { - Konidia elips } \\
\text { - Konodiofor } \\
\text { hialin }\end{array}$ & Aspergillus sp. \\
\hline
\end{tabular}

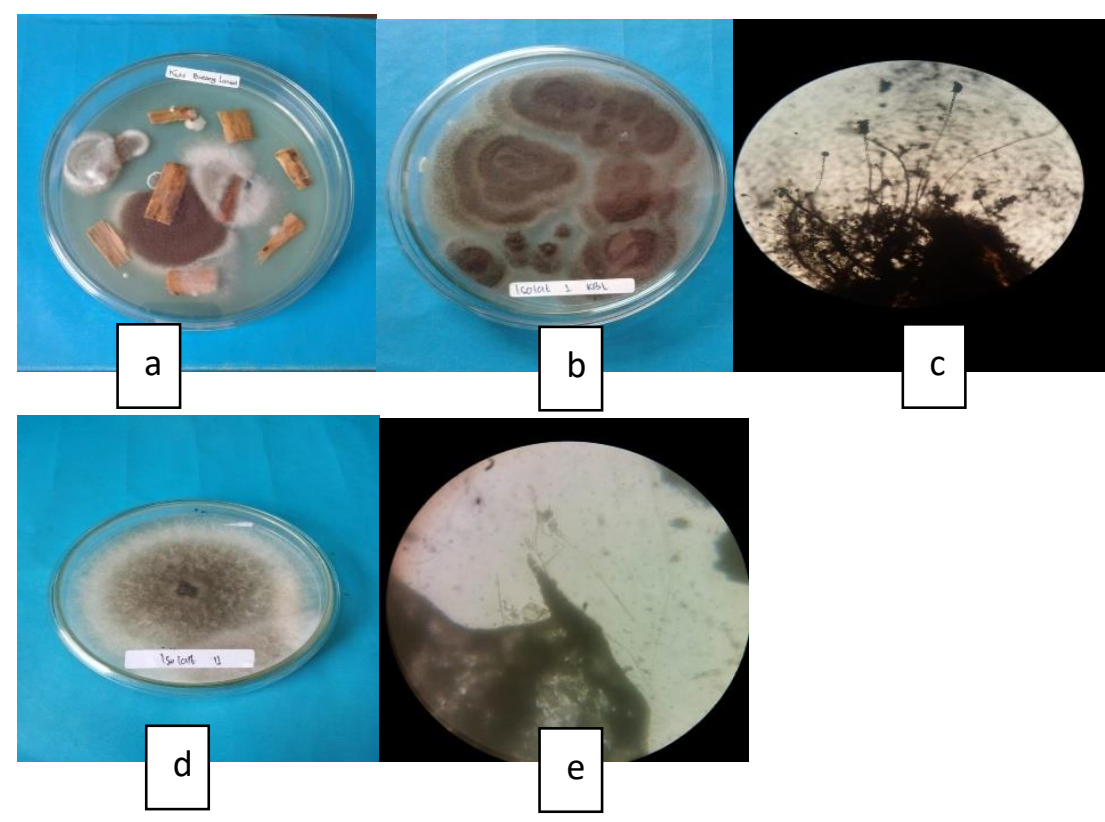

Gambar 1. a. Pertumbuhan fungi endofit pada kulit batang langsat

b. Isolat I secara makroskopik

c. Isolat I secara mikroskopik

d. Isolat II secara makroskopik

e. isolat II secara mikroskopik 
Tabel 3. Hasil pengukuran zona hambat isolat I fungi endofit kulit batang langsat (Lansium domesticum) terhadap Staphylococcus aureus dan Escherichia coli setelah inkubasi 24 jam

\begin{tabular}{ccc}
\hline \multirow{2}{*}{$\begin{array}{c}\text { No. } \\
\text { Replikasi }\end{array}$} & \multicolumn{2}{c}{ Diameter Zona Hambatan $(\mathrm{mm})$} \\
\cline { 2 - 3 } 1 & 10,5 & Escherichia coli \\
\hline 2 & 13,0 & 20,3 \\
3 & 11.5 & 23,1 \\
Jumlah & 35 & 22,4 \\
\hline Rata-rata & 11,67 & 65,8 \\
\hline
\end{tabular}

Tabel 4. Hasil pengukuran zona hambat isolat II kulit batang langsat (Lansium domesticum) terhadap Staphylococcus aureus dan Escherichia coli setelah inkubasi 24 jam

\begin{tabular}{ccc}
\hline \multirow{2}{*}{$\begin{array}{c}\text { No. } \\
\text { Replikasi }\end{array}$} & \multicolumn{2}{c}{ Diameter Zona Hambatan (mm) } \\
\cline { 2 - 3 } 1 & Staphylococcus aureus & Escherichia coli \\
\hline 2 & 10,5 & 20,3 \\
3 & 13,0 & 23,1 \\
\hline Jumlah & 11.5 & 22,4 \\
\hline Rata-rata & 35 & 65,8 \\
\hline
\end{tabular}
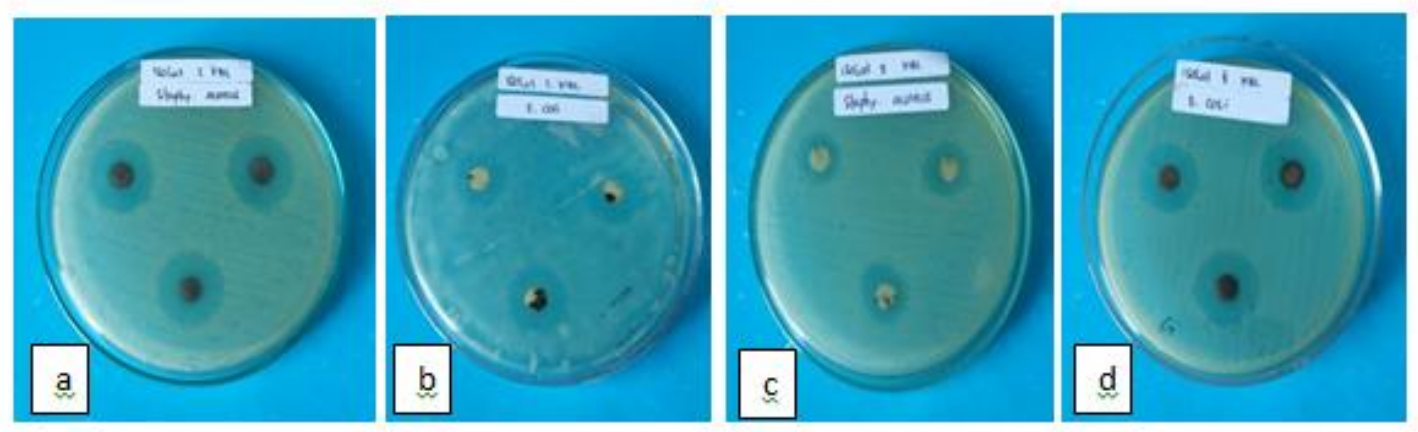

Gambar 2. a. Zona hambat isolat I terhadap Staphylococcus aureus

b. Zona hambat isolat I terhadap Escherichia coli

c. Zona hambat isolat II terhadap Staphylococcus aureus

d. Zona hambat isolat II terhadap Escherichia coli 